\title{
Agricultural Credit Market and Farmers' Response: A Case Study of Turkey
}

\author{
Erdogan Gunes $^{1 *}$, Hormoz Movassaghi
}

${ }^{1}$ Department of Agricultural Economics, Faculty of Agriculture, Ankara University, 06110 Ankara, Turkey ${ }^{2}$ Ithaca College, School of Business, 409 Park Center for Business and Sustainable Enterprises, 14850 Ithaca, New York, USA A R T I C L E I N F O

Research Article
Received 16 August 2016

Accepted 02 December 2016

Keywords:

Agriculture

Credit

Market

Banks

Analytic hierarchy process

${ }^{*}$ Corresponding Author:

E-mail: egunes@agri.ankara.edu.tr \begin{abstract}
A B S T R A C T
Agriculture is an important sector in Turkey's economy. Access to credit financing is critical for timely acquisition of different inputs, farm productivity, and ultimately farmers' financial well-being. Historically, Ziraat Bank and Agricultural Credit Cooperatives, supported by Turkish government, have been the principle supplier of loanable funds in the agricultural sector. However, since 2000, many private banks have discovered the potential of this market and entered the competition. This study was designed to investigate the structure of the agricultural credit market in Turkey and identify factors that influence farmers' preference among alternative lenders. It was found that although the 550 Turkish farmers surveyed had several options among lenders, low interest rates and attainable eligibility criteria emerged as the most important differentiators among banks. Results from the Analytic Hierarchy Process (AHP) demonstrate the rising role of private banks' credit. However, Ziraat Banks' subsidized credits still dominant and its composite weight is $30.74 \%$ of total amount of agricultural credit market.
\end{abstract}

\section{Introduction}

Agriculture is an important sector for Turkey from social and economic vantages. Turkey is an important producer and exporter of agricultural commodities on world markets and is estimated to be the world's 7thlargest agricultural producer. This sector has accounted for $7.4 \%$ of the national income, nearly $20 \%$ of the total workforce, and a major supplier to the domestic food industry. In terms of agricultural lands, Turkey is also one of the largest countries in the world. About $35.5 \%$ of the countries are arable lands and $15 \%$ consists of forests. The cultivated land is around 24 million hectares as per 2015. Around $18.4 \%$ of the cultivated land is irrigated. Vegetable products account for $76 \%$ of total agricultural production, then animal husbandry, meanwhile forestry and fishing contribute a minimal amount. Fruits and field crops make up the most of vegetable products, wheat being the leading crop. As per the figures of 2015, Turkey is the world's biggest producer of hazelnuts, figs, apricots and raisins, the 4th biggest producer of fresh vegetables and grapes, the 6 th biggest producer of tobacco, the 8th biggest producer of wheat, and the 10th biggest producer of cotton. Tea is also large produced and exported (AAT, 2016). To create a sustainable, competitive and organized agricultural sector, Turkey needs to utilize its resources efficiently and effectively. Turkish agriculture needs more credit availability because of certain structural characteristics, notably its small family farm. Most farms are small-scale family farms, fragmented and scattered. The average farm size in Turkey was 5.9 ha in 1991 and reached 6.1 ha in 2001, an increase of only $3.2 \%$ over a decade, according to the last census (Anonymous, 2009). Meanwhile crop and livestock production seasons span periods of time longer in agriculture than other sectors. In agriculture, usually, most products are sold only once a year but costs continue to accrue throughout the year. As such, agricultural production needs continuous infusion of capital for its longevity and success. Furthermore, technological developments such mechanization, increasing use of fertilizer and pesticide, breeding of new varieties and new production methods have all increased farmers' credit demand. The study is important in terms of determining the effective factors in the credit resources of Turkey's farms. Many agricultural credit sources can use research results for determination of strategy with this study.

\section{Overview of Turkish Agricultural Credit Market}

Agriculture in Turkey has had persistent problems which led the country to undergo a radical reform process in the early years of the second millennium. There are major structural problems which include small size of 
agricultural holdings, fragmented and scattered farms, low efficiency, insufficiencies regarding production and marketing infrastructures (Kose, 2012). Agricultural credit has great precaution for their development and they meet their credit requirement from some sources. For many years, the tight monetary policy limited agricultural credit. Historically, farmers relied primarily on formal funds for loans through public sector, alongside with informal sources. Farmers have obtained credit from merchants, wealthy farmers and money lenders. Figure 1 lists the myriad of entities that make up the formal and informal credit sources in Turkey. Currently, farmers can get agricultural credit from a variety of formal sources. Since 2000, however, agricultural sector has opened up to commercial/private banking. With economic development, public monopoly has disappeared and private banking has developed in Turkish agriculture, similar to some emerging economies around the world. Ziraat Bank and private banks originate an important portion (above 90\%) of the farm sector's debt in Turkish Farm Credit system (Gunes and Movassaghi, 2016).

The Ziraat Bank provided most loans to farmers and cooperatives and closely watches agricultural credit.
Although the Bank was intended to favour small farmers in the distribution of credit, its loan requirements restrict credit for the many small farmers who either rent or lack a secure title to land or other properties needed as collateral. Much of the bank's lending consists of short-term loans extended to cooperatives for commodity price support (AP, 2016). The Ziraat Bank, private banks (domestic and foreign-owned and operated), Agricultural Credit Cooperatives, agricultural sales cooperatives and some cooperatives such as Pankobirlik related to sugar processing are the major formal suppliers of credit, while other individuals and institutions constitute informal resources. Wealthy farmers and money lenders are among the informal credit sources, all of whom generally provide short term loans, saddling borrowers with high interest rates and tight payment conditions. They do not work off the record and have historically exercised great power in the development of the credit market, though are likely to decline in importance as the formal sector expands. Farmers who do not have any guarantor are the main customers of the informal sector.

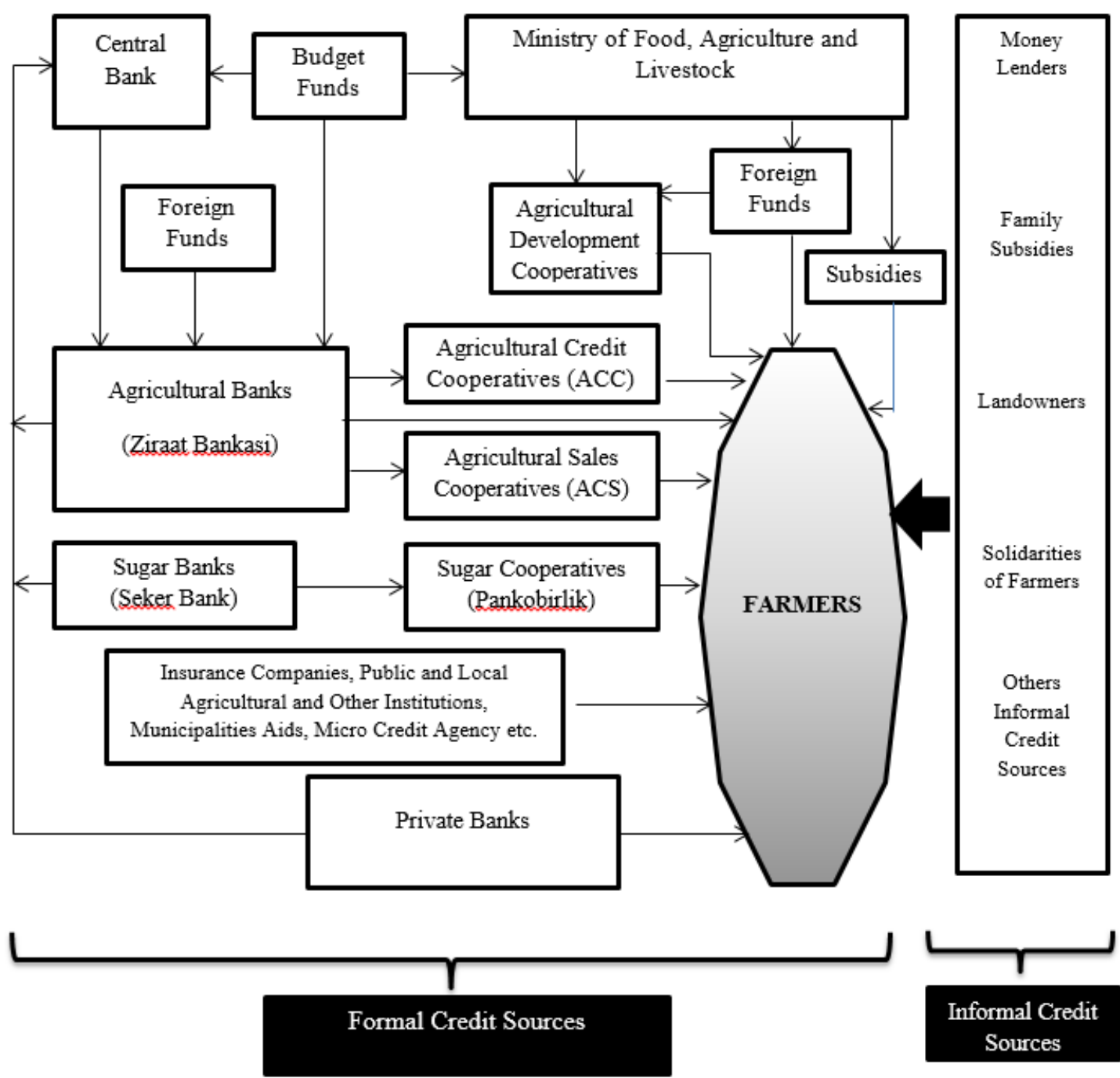

Figure 1 Agricultural financial system and organization in Turkey 
Table 1 Agricultural credit stock of public and private banks

\begin{tabular}{l|ccccc}
\hline \multicolumn{1}{c}{ Years } & Public Banks (US \$) & Rate $(\%)$ & Private Banks (US \$) & Rate $(\%)$ & Total \\
\hline 2007 & $2,288,756$ & 66.2 & $1,169,882$ & 33.8 & $3,458,638$ \\
2008 & $2,843,971$ & 64.1 & $1,589,628$ & 35.9 & $4,433,600$ \\
2009 & $3,617,676$ & 70.2 & $1,539,131$ & 29.8 & $5,156,807$ \\
2010 & $5,762,615$ & 73.3 & $2,103,304$ & 26.7 & $7,865,919$ \\
2011 & $7,923,929$ & 74.3 & $2,741,861$ & 25.7 & $10,665,790$ \\
2012 & $7,844,235$ & 69.8 & $3,399,429$ & 30.2 & $11,243,664$ \\
2013 & $8,018,389$ & 63.8 & $4,557,143$ & 36.2 & $12,575,532$ \\
2014 & $10,154,971$ & 64.2 & $5,660,659$ & 35.8 & $15,815,630$ \\
2015 & $13,538,849$ & 66.7 & $6,772,325$ & 33.3 & $20,311,174$ \\
Average & $6,888,154$ & 67.7 & $3,281,485$ & 32.3 & $10,169,639$ \\
\hline
\end{tabular}

Sources: BDDK (2015).

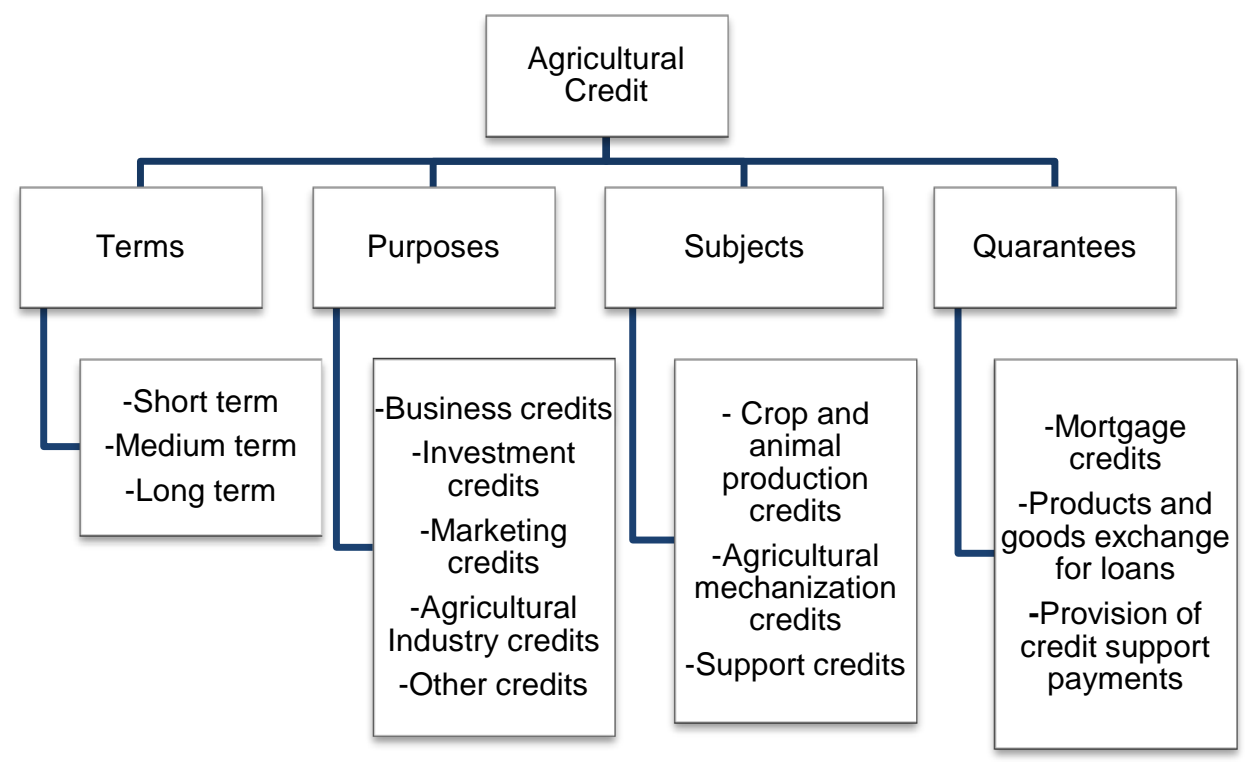

Figure 2 Classification of Various Aspects of Agricultural Credit (Gunes, 2011)

For many years, agriculture sector was financed solely by the Ziraat Bank, founded in 1863, and the Turkish Agricultural Credit Cooperatives which conducted their activities under the directorship of Ziraat Bank for a long time. The share of Ziraat Bank in agricultural lending market has however dropped to around $60 \%$ in spite of its monopoly in the disbursement of subsidized loans and agricultural subsidies (Yildiz and Kocoglu, 2015). Commercial banks, on the other hand, have become an important financial source in agriculture sector in Turkey in recent years offering specialized agricultural credits and credit packages. They are interested in agriculture due to high profit margin involved and the long term growth potential of that sector.

Table 1 shows the development of the agricultural credit between 2007 and 2015. During this period, agricultural credit increased 5.8 folds, increasing from nearly $\$ 3.5$ billion in 2007 to $\$ 10.7$ billion in 2010 and $\$ 20.3$ billion by 2015 , with Ziraat Bank suppling $27.7 \%$ of the total credit offered and private banks $32.3 \%$, on average. During the 1990s, Ziraat Bank's share of the Turkish agricultural credit decreased from $90 \%$ to $66.7 \%$ (Gunes and Artukoglu, 2010).

Among banks, the farmer-owned Agricultural Credit Cooperatives is another important source of formal production credits for farmers, especially the small-scale producers. These cooperatives have had small but growing share, increasing their loans from $\$ 180$ million in 2002 to $\$ 1.8$ billion in 2010 (Borlu, 2015) and \$2.4 billion in 2015 (Unluer and Gunes, 2016). Many agricultural credit types and policy application were used in agricultural sector in Turkey (Figure 2).

Business credits are opened to meet any needs of business. They are used to finance expenses such as seeds, seedlings, fertilizers, pesticides, feed, vaccines, juvenile, labour, fuel, tillage, harvesting, threshing, marketing, electricity, water, and maintenance, insurance. Their terms increased from 12 months to 24 months with the latest regulations. Investment credits are used to purchase or construct a company's fixed assets. They are used in investments of greenhouses, barns, warehouses, buildings, orchards, machinery etc. Their terms increased from 5 years to 7 years with the latest regulations. Many banks offer to farmers some non-specialized credits such as support credits and transport vehicles. As it can be seen that, banking system has important places within the agricultural credit policy and this development will go on liberalization economic system. 


\section{Material and Methodology}

Data used in this research was obtained through a survey of 550 randomly selected farmers in Antalya, Konya, Ankara, Karaman and Eskisehir provinces, which are among the top 10 provinces in Turkey in terms of agricultural credit usage. All surveys are selected randomly and equally distributed across the fives. In each province, we selected 110 farmers. In general, the structure of Turkish farming system is dominated by small scale of farms. Data base is provided with survey research for these farms because of not record keeping. The selected research area is representative example of Turkish farming system with regard to credit usage and production varieties (Figure 3). Selected provinces are important for usage of agricultural credit. Konya, Ankara and Antalya takes place among top 10 with regard to agricultural credit usage, and others are important also for credit and production patterns. All of them consist of approximately $15.2 \%$ of total agricultural credit amount at 2014 in Turkey according to Finturk database (http://ebulten.bddk.org.tr/finturk). Many production systems such as field crops, greenhouse and orchard, vegetable and animal production were applied at selected area. As part of the interview, farmers were asked to identify the criteria that they had used in selecting among the 11 banks offering agricultural credit. Table 2 summarizes farmers' responses. Low interest rate, eligible term, flexible payment plan, loyalty, location advantage, promotion and "other" reasons (e.g., willingness to work with the same banks, psychological and risky considerations, perception of public banks) were mentioned as the most widely used criteria.

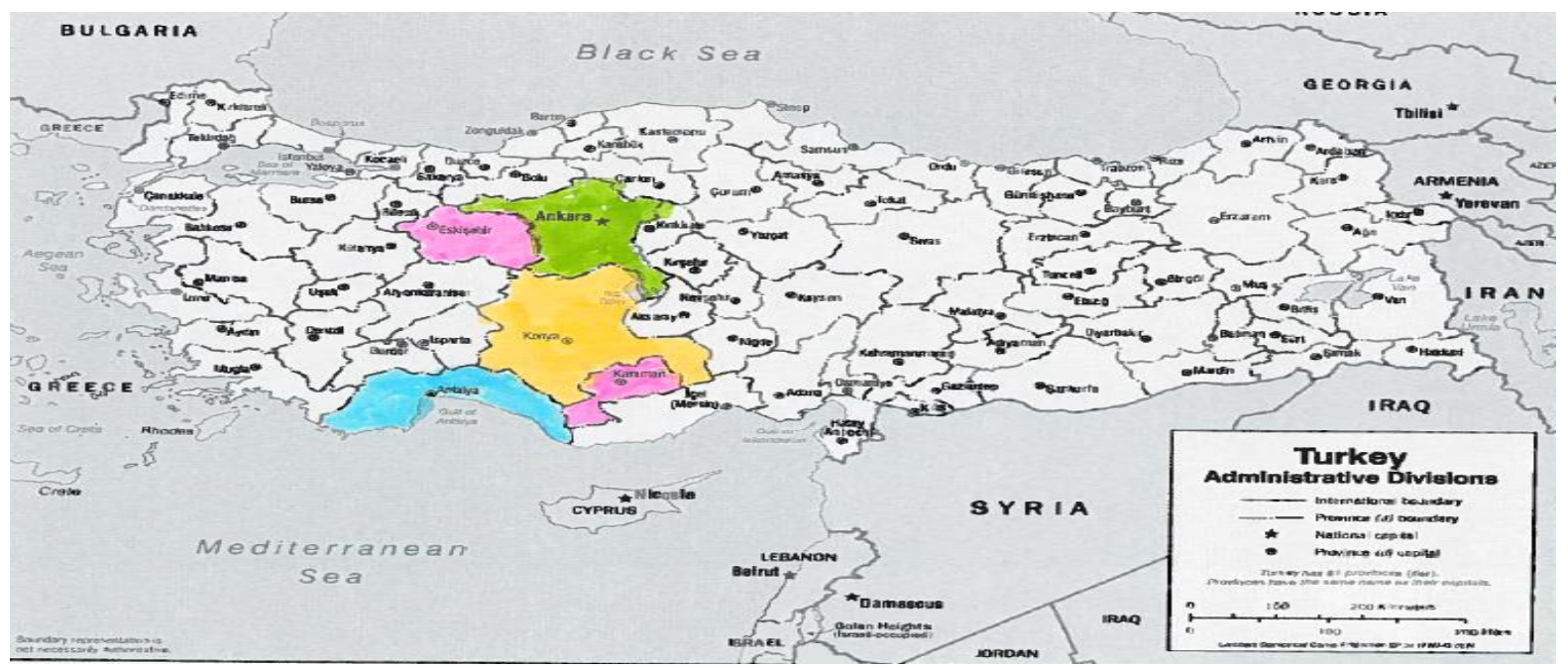

Figure 3 Selected research area

Table 2 Hierarchy for the bank selection problem

\begin{tabular}{|c|c|c|c|c|c|c|c|}
\hline AIM & \multicolumn{7}{|c|}{ Bank Selection } \\
\hline \multirow{2}{*}{ Criteria } & Low Interest & Eligibility & Flexible & & Location & & Other \\
\hline & Rate & Terms & Payment Plan & Loyalty & Advantage & Promotion & Reasons \\
\hline \multirow{11}{*}{ Banks } & $\mathrm{ZB}$ & ZB & $\mathrm{ZB}$ & ZB & ZB & $\mathrm{ZB}$ & ZB \\
\hline & DB & DB & DB & DB & DB & DB & DB \\
\hline & TEB & TEB & TEB & TEB & TEB & TEB & TEB \\
\hline & VB & VB & VB & VB & VB & VB & VB \\
\hline & ISB & ISB & ISB & ISB & ISB & ISB & ISB \\
\hline & YKB & YKB & YKB & YKB & YKB & YKB & YKB \\
\hline & $\mathrm{HB}$ & $\mathrm{HB}$ & $\mathrm{HB}$ & $\mathrm{HB}$ & $\mathrm{HB}$ & $\mathrm{HB}$ & $\mathrm{HB}$ \\
\hline & SB & SB & SB & SB & SB & SB & SB \\
\hline & $\mathrm{AB}$ & $\mathrm{AB}$ & $\mathrm{AB}$ & $\mathrm{AB}$ & $\mathrm{AB}$ & $\mathrm{AB}$ & $\mathrm{AB}$ \\
\hline & GB & GB & GB & GB & GB & GB & GB \\
\hline & $\mathrm{FB}$ & FB & FB & FB & $\mathrm{FB}$ & FB & FB \\
\hline
\end{tabular}

Note: Banks' full names are as follow: ZB=ZiraatBankasi, DB=Deniz bank, TEB=TurkiyeEkonomiBankasi, VB=Vakifbank, ISB=Is Bankasi, $\mathrm{YKB}=$ YapiKrediBankasi, $\mathrm{HB}=$ Halkbank, $\mathrm{SB}=$ Sekerbank, $\mathrm{AB}=\mathrm{Akbank}, \mathrm{GB}=$ GarantiBankasi, FB= Finans $\mathrm{Bank}$

Analytic Hierarchy Process (AHP) was used to identify the criteria that farmers use in their selection process. AHP method is one of the most flexible and easily implemented multi criteria decision making techniques which develops a graphical representation of the problem in terms of the objective, the criteria and the decision alternatives. The popularity of the AHP is due to its simplicity, flexibility, ease of use and interpretation in analysing complex decision problems (Yilmaz, 1999). The oldest reference that we have found this dates (Saaty, 1972). It is one of the most popular multi criteria decision making methodologies available today that is applied in 
many diverse fields. Zahedi (1986) has provided one of the earliest reviews of AHP. She has outlined four decision steps of AHP and categorized the diverse application fields of AHP in terms of evaluation, selection and prediction. Forman and Gass (2001) and Sipahi and Timor (2010) have discussed applications of AHP for decisions such as choice, prioritization/evaluation, resource allocation, benchmarking, quality management, public policy, health care and strategic planning. Vaidya and Kumar (2006) has reviewed many papers under many themes and they have found that AHP was predominantly used in engineering, personal and social sectors. Related to AHP application have focused some reviews marketing (Wind and Saaty, 1980; Mark 2001), energy (Pohekar and Ramachandran, 2004), medical and health care decision making (Liberatore and Nydick, 2008), research and development (R\&D) project selection and resource allocation (Heidenberger and Stummer, 1999), banks (Secme et al., 2009; Haghighi et. al., 2010), strategy selection (Li and Li, 2009; Limam et al., 2009; Wu et al., 2009; Chen and Wang, 2010).

To deal with the AHP problems, Saaty (1980) proposed four basic steps. The first step is modelling and at this stage involves making construction of a hierarchy at different levels of criteria and alternatives.

Secondly, valuation level is based on a 1-9 ratio-scale measure. It is necessary to make pairwise comparisons, rating the relative importance between each pair of decision alternatives and criteria. It is a theory of measurement concerned with dominance priorities from pairwise comparison of elements with respect to a common criterion. During the AHP process, the rating scale described in Table 3 was used. The matrix $A$ is a $m \times m$ real matrix, where $m$ is the number of evaluation criteria considered. Each entry $a_{j k}$ of the matrix Arepresents the importance of the $j$ th criterion relative to the $k$ th criterion. If $a_{j k}>1$, then the $j$ th criterion is more important than the $k$ th criterion, while if $a_{j k}<1$, then the $j$ th criterion is less important than the $k$ th criterion. If two criteria have the same importance, then the entry $a_{j k}$ is 1 . The entries $a_{j k}$ and $a_{k j}$ satisfy the following constraint:

$$
a_{j k} \cdot a_{k j}=1
$$

The relative importance between two criteria is measured according to a numerical scale from 1 to 9 , as shown in Table 3, where it is assumed that the $j$ th criterion is equal or more important than the $k$ th criterion. The phrases in the "Interpretation" column of Table 3 are only suggestive, and may be used to translate the decision maker's qualitative evaluation of the relative importance between two criteria into numbers. It is also possible to assign intermediate values which do not correspond to a precise interpretation. The values in the matrix Aare by construction pairwise consistent (DIISM, 2016; Saaty, 1990).

The third stage is prioritization which is using prioritization methods to derive local priorities of the objectives at each level of the hierarchy. Once the matrix $\mathrm{A}$ is built, it is possible to derive from A the normalized pairwise comparison matrix $\mathrm{A}_{\text {norm }}$ by making equal to 1 the sum of the entries on each column, i.e. each entry $\bar{a}_{j k}$ of the matrix $\mathrm{A}_{\text {norm }}$ is computed as;

$$
\bar{a}_{j k}=\frac{a_{j k}}{\sum_{l=1}^{m} a_{l k}}
$$

Last one is the synthesis and at this stage criteria weight vector $w$ (that is an $m$-dimensional column vector) is built by averaging the entries in each row of $\mathrm{A}_{\text {norm }}$, i.e.

$$
W_{j}=\frac{\sum_{l=1}^{m} \bar{a}_{j l}}{m}
$$

The AHP allows consideration of both objective and subjective factors in selecting the best alternative.

Table 3 Pairwise comparison scale for AHP preferences

\begin{tabular}{l|c}
\hline \multicolumn{1}{c|}{$\begin{array}{c}\text { Verbal Statement of Preferences } \\
\text { (Interpretation) }\end{array}$} & $\begin{array}{c}\text { Value of } \\
\mathrm{a}_{\mathrm{j} k}\end{array}$ \\
\hline $\begin{array}{l}\text { Extremely preferred ( } \mathrm{j} \text { is absolutely more } \\
\text { important than } \mathrm{k} \text { ) }\end{array}$ & 9 \\
$\begin{array}{l}\text { Very strongly preferred (j is strongly more } \\
\text { important than } \mathrm{k})\end{array}$ & 7 \\
$\begin{array}{l}\text { Strongly preferred ( } \mathrm{j} \text { is more important than } \\
\mathrm{k})\end{array}$ & 5 \\
$\begin{array}{l}\text { Moderately preferred ( } \mathrm{j} \text { is slightly more } \\
\text { important than } \mathrm{k})\end{array}$ & 3 \\
$\begin{array}{l}\text { Equally preferred }(\mathrm{j} \text { and } \mathrm{k} \text { are equally } \\
\text { important) }\end{array}$ & 1 \\
\hline Note: Numerical rating of $2,4,6$, and 8 will use scale as middle values.
\end{tabular}

The final step is to calculate the Consistency Index (CI) by using the table below, derived from Saaty's book, in which the upper row is the order of the random matrix and the lower row is the corresponding index of consistency for random judgements. Each of the numbers in this table is the average of CI's derived from a sample of randomly selected reciprocal matrices using the AHP scale (CJCU, 2016).

Consistency is a basic requirement for comparison matrices to guarantee meaningful results (Zhu et al., 2016). Consistency Index is deviation or degree of consistency using the following formula:

$$
C I=\frac{x-m}{m-1}
$$

The average random consistency index of sample size 500 matrices is shown Table 4. A perfectly consistent decision maker should always obtain $C I=0$, but small values of inconsistency may be tolerated. In particular, if

$$
\frac{C I}{R I}<0.1
$$

Inconsistencies are tolerable and acceptable and a reliable result may be expected from the AHP. (DIISM, 2016). If this ratio is greater than $10 \%$, we need to revise the subjective judgment (CJCU, 2016). 
Table 4 Values of the random index (RI)

\begin{tabular}{l|c}
\hline \multicolumn{1}{c|}{$\mathrm{m}$} & $\mathrm{RI}$ \\
\hline 1 & 0.00 \\
2 & 0.00 \\
3 & 0.58 \\
4 & 0.90 \\
5 & 1.12 \\
6 & 1.24 \\
7 & 1.32 \\
8 & 1.41 \\
9 & 1.45 \\
10 & 1.49 \\
11 & 1.51 \\
12 & 1.48 \\
13 & 1.56 \\
14 & 1.57 \\
\hline
\end{tabular}

\section{Results and Discussion}

As farming developed in the provinces surveyed, farmers' financial need increased accordingly. Based on farmers' response, Ziraat Bank and Agricultural Credit Cooperatives provided $62.5 \%$ of the loans while private banks gave $30.5 \%$. Survey results showed that short term credit were used largely for funding of the operating capital requirements of farmers while middle and long term credit were utilized for purchasing assets such as land, tractors, breeding animals, irrigation system etc. On average, farmers used short-term credit $68 \%$ of the times and medium and long-term credit in $32 \%$ of the cases, during 2012-2014.

There was intense competition in the credit market in our researched areas. All private banks supplied loans in spite of the supporting of Ziraat Bank by government by means of disbursement of subsidized loans and agricultural subsidies. Based on survey from all farmers, it was found that on average, $34.95 \%$ of them received some type of supports from government. The most important support was fuel payment and direct income payment as well. In fact, alongside the semi privatization of the agricultural credit market, government has offered subsidized credit through low interest rate by the Ziraat Bank in Turkey. Other commercial banks have higher interest rate and this explains why some farmers prefer to have loan from Ziraat Bank. Meanwhile, private banks have tried to meet farmers' demand through their product offerings, promotion activities, quick credit evaluation and disbursement, matching loan maturity with production, client and field visits, and easy guarantee.

Table 5 below shows farmers' preferences among banks based on their various selection criteria. We can see the importance of Ziraat Bank for farmers. As a major institution from formal credit suppliers, Ziraat Bank was distributing government funds directly or through other channels until 2002. The Bank's organizational structure was completely transformed into joint-stock company in that year. When the Reform Policy Program was put into practice, Ziraat Bank reduced its agricultural loans portfolio sharply. Agricultural Reform Implementation
Project was a move towards a market oriented agriculture policy by the abolition of administered prices and of input and credit subsidies, a restructuring of agricultural stateowned enterprises and agricultural sales cooperatives, the introduction of the Direct Income Support scheme (DIS), and gradual reduction of tariffs and the restructuring of the agricultural production. Under the reform program, output price supports, input subsidies and grants in various forms were to be phased out and replaced by direct payments to farmers based on land holding (decoupled from type or quantity of production (Kose, 2012). Today, its agricultural direct lending operations are channelled mainly to larger farms and state-owned holdings, despite the current regulation that identifies small farm holders as the target client. In this context, Ziraat Bank can also extend credits to individual farmers directly for middle or long term, provided that customer meets strict credit requirements (Oskam et al., 2004).

As it can be seen in Table 5, low interest rate was the main reason for farmers' preference for Ziraat Bank. Farmers had the opportunity to obtain agricultural operating and investment loans with annual interest rates varying from $0 \%$ to $8.25 \%$ within subsidy ratios set on the basis of production scopes in relevant decrees (Ziraat Bankasi, 2013). The other commercial banks such as DB, ISB, HB and SBranked next in farmers' preferences in terms of low interest rate, which incidentally cannot be lower than Ziraat Bank. We can also see farmers' preference for Ziraat Bank as it related to eligibility term, different payment plan, loyalty, location advantage, though not quite as important as low interest rate. Historically, a loyalty has developed between that bank and farmers as it was a unique and specialized bank dedicated to the development of the farm sector for ages. Farmers did not know any other bank matching their needs. Ziraat Bank has also a wide network of branch established in every town. As such, it has continuously been in touch with farmers and their needs and wants. Actually, offering subsidized credit is one of the main reason of Ziraat Bank's popularity.

Deniz Bank was the second preferred bank after the Ziraat Bank in terms of all selection criteria except for promotion. Actually this banks has a long history of involvement in the agricultural sector because it took over from agricultural cooperatives. Lately, it wants to increase agricultural credit offerings for many different uses and different agricultural farming system. Generally, all banks are trying to develop expertise for different areas of farms and meet farmer credit demand with their special agricultural credit card.

In short, based on AHP model, the first preference is ZB followed by DB. Other preferences include SB, ISB and $\mathrm{HB}$, respectively. Results show that credit market has become more diverse and competitive despite subsidized credit offered by Ziraat Bank. In future, government may retreat from this market because of its heavy financial load. At this juncture, all banks should develop a precise understanding of the agricultural sector and its different financial cash flow streams. All banks have to adjust their portfolio based on the unique characteristics of the 
farming sector. This market has the potential to be developed because of the increasing of credit requirements of the farm sector to the benefit of all stakeholders.

The least preferred banks, on the other hand, were GB and FB banks based on the composite weights. Choice $\mathrm{ZB}$ was 2.17 times more preferable than $\mathrm{DB}$, and $\mathrm{DB}$ is 2.00 times more preferable than TEB (Table 6).
We can also check the overall consistency of the hierarchy by summing for all levels, with weighted consistency ratio in the nominator and weighted consistency index in the denominator. Overall consistency of the hierarchy in this research came to be $1.80 \%$ on average, which is less than $10 \%$ and acceptable.

Table 5 Preference for banks offering agricultural credit according to selection criteria (\%)

\begin{tabular}{|c|c|c|c|c|c|c|c|c|c|c|c|}
\hline \multirow{2}{*}{$\begin{array}{c}\text { Criteria } \\
\text { Low Interest Rate }\end{array}$} & \multicolumn{11}{|c|}{ Banks } \\
\hline & $\mathrm{ZB}$ & DB & TEB & VB & ISB & YKB & HB & SB & $\mathrm{AB}$ & GB & FB \\
\hline No Preference & 26.91 & 82.55 & 97.45 & 98.55 & 94.73 & 98.18 & 94.55 & 95.45 & 99.27 & 99.45 & 99.45 \\
\hline Preference & 73.10 & 17.46 & 2.54 & 1.45 & 5.28 & 1.82 & 5.44 & 4.54 & 0.72 & 0.54 & 0.54 \\
\hline \multicolumn{12}{|l|}{ Eligible Term } \\
\hline No Preference & 34.36 & 79.45 & 95.09 & 97.45 & 94.18 & 96.18 & 93.45 & 94.91 & 98.91 & 99.45 & 99.45 \\
\hline Preference & 65.64 & 20.55 & 4.91 & 2.54 & 5.82 & 3.81 & 6.54 & 5.10 & 1.08 & 0.54 & 0.54 \\
\hline \multicolumn{12}{|c|}{ Flexible Payment Plan } \\
\hline No Preference & 43.82 & 78.36 & 94.55 & 97.45 & 94.00 & 96.36 & 93.64 & 94.73 & 98.73 & 99.82 & 99.27 \\
\hline Preference & 56.19 & 21.63 & 5.46 & 2.54 & 6.00 & 3.64 & 6.36 & 5.27 & 1.27 & 0.18 & 0.73 \\
\hline \multicolumn{12}{|l|}{ Loyalty } \\
\hline No Preference & 48.91 & 89.45 & 97.82 & 98.91 & 95.82 & 97.82 & 95.64 & 96.36 & 98.91 & 99.64 & 99.64 \\
\hline Preference & 51.10 & 10.55 & 2.18 & 1.08 & 4.19 & 2.19 & 4.37 & 3.63 & 1.08 & 0.36 & 0.36 \\
\hline \multicolumn{12}{|c|}{ Location Advantage } \\
\hline No Preference & 75.45 & 90.18 & 96.73 & 98.55 & 96.91 & 98.00 & 98.18 & 97.27 & 99.45 & 99.45 & 100.00 \\
\hline Preference & 24.55 & 9.82 & 3.28 & 1.46 & 3.10 & 2.01 & 1.83 & 2.73 & 0.54 & 0.54 & 0.00 \\
\hline \multicolumn{12}{|l|}{ Promotion } \\
\hline No Preference & 92.00 & 86.73 & 97.09 & 99.64 & 98.73 & 99.82 & 98.73 & 99.45 & 99.82 & 99.64 & 99.82 \\
\hline Preference & 7.99 & 13.27 & 2.90 & 0.36 & 1.27 & 0.18 & 1.27 & 0.54 & 0.18 & 0.36 & 0.18 \\
\hline \multicolumn{12}{|l|}{ Other reasons } \\
\hline No Preference & 75.82 & 96.91 & 99.09 & 99.09 & 97.82 & 98.00 & 98.00 & 98.55 & 99.82 & 99.64 & 99.45 \\
\hline Preference & 24.18 & 3.08 & 0.91 & 0.90 & 2.19 & 2.00 & 1.99 & 1.45 & 0.18 & 0.36 & 0.54 \\
\hline
\end{tabular}

Note: Preferences consist of the sum of the first, second, third and fourth preferences of farmers

Table 6 Overall composite weight of the alternatives

\begin{tabular}{|c|c|c|c|c|c|c|c|c|c|}
\hline \multirow{2}{*}{ Banks } & \multicolumn{7}{|c|}{ Criteria } & \multirow{2}{*}{ CW } & \multirow{2}{*}{ PR } \\
\hline & LIR & ET & FPP & $\mathrm{L}$ & LA & $\mathrm{P}$ & $\mathrm{OF}$ & & \\
\hline ZB & 0.0821 & 0.0901 & 0.0691 & 0.0382 & 0.0149 & 0.0026 & 0.0104 & 0.3074 & 1 \\
\hline DB & 0.0322 & 0.0404 & 0.0349 & 0.0149 & 0.0086 & 0.0067 & 0.0039 & 0.1417 & 2 \\
\hline TEB & 0.0153 & 0.0194 & 0.0160 & 0.0078 & 0.0057 & 0.0030 & 0.0031 & 0.0705 & 6 \\
\hline VB & 0.0115 & 0.0144 & 0.0125 & 0.0063 & 0.0039 & 0.0025 & 0.0029 & 0.0541 & 8 \\
\hline ISB & 0.0181 & 0.0198 & 0.0155 & 0.0078 & 0.0041 & 0.0028 & 0.0033 & 0.0714 & 5 \\
\hline YKB & 0.0127 & 0.0157 & 0.0131 & 0.0078 & 0.0038 & 0.0026 & 0.0030 & 0.0588 & 7 \\
\hline $\mathrm{HB}$ & 0.0205 & 0.0188 & 0.0158 & 0.0094 & 0.0038 & 0.0028 & 0.0030 & 0.0740 & 4 \\
\hline SB & 0.0197 & 0.0207 & 0.0161 & 0.0079 & 0.0044 & 0.0025 & 0.0030 & 0.0744 & 3 \\
\hline $\mathrm{AB}$ & 0.0103 & 0.0123 & 0.0112 & 0.0070 & 0.0036 & 0.0026 & 0.0030 & 0.0501 & 9 \\
\hline GB & 0.0103 & 0.0115 & 0.0112 & 0.0067 & 0.0037 & 0.0025 & 0.0030 & 0.0488 & 10 \\
\hline FB & 0.0103 & 0.0115 & 0.0112 & 0.0067 & 0.0037 & 0.0025 & 0.0030 & 0.0488 & 10 \\
\hline $\mathrm{PC}(\%)$ & 24.31 & 27.46 & 22.66 & 12.06 & 6.03 & 3.33 & 4.15 & 1.0000 & \\
\hline
\end{tabular}

LIR: Low Interest Rate, ET: Eligible Term; FPP: Flexible Payment Plan, L: Loyalty, LA: Location Advantage, P: Promotion, OF: Other factors, CW: Composite Weight, PR: Priority Ranking, PC: Proportion of criteria (\%), X: 11.2718, CI: 0.02718, RI: 1.51 , Consistency ratio: 0.018 (1.80 \%) (Acceptable)

\section{Conclusions}

Turkish farming system has been growing and farmers' credit demand has and will continue to increase in the future along with it in order to meet such short term needs as purchasing fuel and long run purposes such as investment in land, irrigation facilities and machinery. Consequently, many private banks have been drawn to this sector and offer different kinds of credit to the farmers. Many of them have established departments related to agricultural banking, especially private banks as they try to understand farming system and this is why they want to employ agricultural experts. Lately, there has been an increasing number of agriculturist employee 
transfer from public banks to private banks. Private Banks have been engaged in offering attractive options to farmers and they want to offer more flexible payment plans as evidenced through their advertisement and promotional activities. At the same time, farmers are faced with new techniques related to agricultural credit including mobile banking, branchless banking, and mobile payment systems. The ultimate goal of all these measures is to increase access to credit sources.

One of the main determinants of demand for credit is its cost and subsidized credit will decrease credit cost for farmers. In our surveyed areas, farmers have more confidence in Ziraat Bank as a public bank and because of giving subsidized credit. There are historical connections between farmers and Ziraat Bank and a sense of loyalty to it. Currently, only Ziraat Bank offers subsidized credit. However, all private banks want to give subsidized loans to farmers using subsidized credit. Private Banks are essential to the development of farming activities and offering agricultural credits can be more attractive for private sector.

Agricultural credit is very important for the growth of the farming sector. Banking activities for agriculture should increase with low interest rate and utilization of payment. In order to utilize its full potential, farmer's education should be increased and their management ability will need to be developed by information and field training. Agricultural development needs financial support and financial sector needs to be more active in the agricultural sector. There is a need for more communication and coordination in the implementation of credit facilities between farmers and banks. They will need more technical and operating information and communication technology during the credit usage. Credit should be provided on time and payment conditions like a guarantee must be suitable for farmers' plan, because timing in agriculture is crucial. Currently, loan bureaucracy has decreased in some private banks and access to credit has eased, enabling some farmers to move from subsistence/semi-commercial into commercial farmers. Turkish farming system has been growing and farmers' credit demand will continue to increase in the future along with it, in order to meet such short term needs as purchasing fuel and long run purposes such as investment in land, irrigation facilities and machinery. Our research findings should assist banks in modifying their loan policies and procedures in order to expand their market share resulting in more competition in the process and decreased of cost of credit for farmers, a win-win situation for all participants, resulting in a more robust agricultural credit market, growth of the vital agricultural sector and the improved financial well-being of the farmers.

\section{Acknowledgment}

This study was prepared while Erdogan Gunes was a visiting scholar in the School of Business at Ithaca College. This project was supported by a scholarship from
Scientific and Technological Research Council of Turkey (TUBITAK) program 2219.

\section{References}

AAT. 2016. http://www.allaboutturkey.com/agriculture.htm (Accessed by 22.11.2016)

Anonymous. 2009. Ekonomik GostergelerleT urkiye'de Tarim 2008. Tarımsal Ekonomi ve Politika Gelistirme Enstitusu. Ankara.

AP. 2016. Agricultural Policy. http://countrystudies.us/turkey/ 57.htm (Accessed by 22.11.2016)

BBDK. 2015. Financial Indicators, http://www.bbdk.com(Accessed by $11 / 07 / 2016)$.

BDDK. 2016. http://ebulten.bddk.org.tr/finturk (Accessed by 10.08.2016).

Borlu Y. 2015. A story of post-fordistexploitation: Financialization and small-scale maize farmers in Turkey.Rural Sociology.DOI: 10.1111/ruso.12061.

Chen MK, Wang SC. 2010. The critical factors of success for information service industry in developing international market: Using analytic hierarchyprocess (AHP) approach. Expert Systems with Applications., 37: 694-704.

CJCU. 2016. http://web.cjcu.edu.tw/ lcc/Courses/TUTORIAL /AHP\%20Tutorial.doc (Accessed by 07/11/ 2016)

DIISM. 2016. http://www.dii.unisi.it/ mocenni/Note_AHP.pdf (Accessed by 01/08/2016)

Forman E, Gass S. 2001. The analytic hierarchy process-An exposition. Operations Research, 49(4): 469-486.

Gunes E. 2011. Tarim Isletmelerinin Finansmani, Tarım ekonomisi. Anadolu Üniversitesi Yayını No: 2266, Eskisehir.

Gunes E, Artukoglu MM. 2010. Agricultural Credit Efficiency and Applications in Turkey during Global Financial Crisis. Turkey IX. Agricultural Economics Congress,pp.795-801, Sanlurfa, (In Turkish).

Gunes E, Movassaghi H. 2016. Agricultural Credit System in US and Suggestions for Turkish Farming, Turkish XII. Agricultural Economics Congress, pp. 1713-1722.Isparta (In Turkish).

Haghighi M, Divandari A, Keimasi M. 2010. The impact of 3D ereadiness on e-banking development in Iran: A fuzzy AHP analysis. Expert Systems with Applications, 37: 4084-4093.

Heidenberger K, Stummer C. 1999. Research and development project selection and resource allocation: a review of quantitative modelling approaches. International Journal of Management Reviews, 1: 197-224.

Kose MA. 2012. Agricultural Policy Reforms and Their Implications on Rural Development: Turkey and The EU, Ankara Avrupa Çalışmaları Dergisi Cilt: 11, No: 2: 75-98.

Li S, Li JZ. 2009. Hybridizing human judgment, AHP, simulation and a fuzzy expert system for strategy formulation under uncertainty. Expert Systems with Applications, 36: 5557-5564.

Liberatore M, Nydick R. 2008. The analytic hierarchy process in medical and health care decision making: A literature review. European Journal of Operational Research, 189(1): 194-207.

Limam MS, Reijers H, Ounnar F. 2009. Development of a decisionmaking strategy to improve the efficiency of BPR. Expert Systems withApplications, 36: 3248-3262.

Mark D. 2001. Adaptive AHP: a review of marketing applications with extensions. European Journal of Marketing, 35 (7/8): 872894.

Oskam A, Bursell A, Temel T, Beckum SV, Longworth N, Vilchez M. 2004. Turkey in EU, Consequences for Agriculture. Food, Rural Areas and Structural Policy Report, Holland.

Pohekar SD, Ramachandran M. 2004. Application of multi-criteria decision making to sustainable energy planning - a review. Renewable and Sustainable EnergyReviews,8: 365-381.

Saaty T. 1972. An Eigenvalue Allocation Model for Prioritization and Planning. Energy Management and Policy Center. University of Pennsylvania, Working Paper. 
Saaty T.L. 1990. How to make a decision: The Analytic Hierarchy Process. European Journal of Operational Research, 48: 9-26.

Saaty TL. 1980. The Aanalytic Hierarchy Process. In NewYork.

Secme NY, Bayrakdaroglu A, Kahraman C. 2009. Fuzzy performance evaluation in Turkish banking sector using analytic hierarchy process and TOPSIS. Expert Systems with Applications, 36: 11699-11709.

Sipahi S, Timor M. 2010. The analytic hierarchy process and analytic network process: an overview of applications. Management Decision, 48 (5): 775-808.

Unluer M, Gunes E. 2016. Development in Turkish Agricultural Credit Markets and its impact on the agricultural holdings. Turkish XII. Agricultural Economics Congress, pp.319-329, Isparta (In Turkish).

Vaidya O, Kumar S. 2006. Analytic hierarchy process: An overview of applications. European Journal of Operational Research, 169(1): 1-29.

Wind Y, Saaty TL. 1980. Marketing applications of the Analytic Hierarchy Process. Management Science, Vol.26 (7): 641-658.
Wu CR, Lin CT, Lin YF. 2009. Selecting the preferable ban assurance alliance strategic by using expert group decision technique. Expert Systems withApplications, 36: 3623-3629.

Yildiz M, Kocoglu E. 2014. A different view on agricultural banking, Agrotime. 8-15.

Yilmaz E. 1999. Solving multiple criteria decision making problems using the analytic hierarchy process. Eastern Mediterranean Forestry Research Institute, The journal of Eastern Mediterranean Forestry, 5: 95-122.

Zahedi F. 1986. The analytic hierarchy process: A survey of the method and its applications. Interface, 16(4) : 96-108.

Zhu B, Xu Z, Zhang R, Hong M. 2016. Hesitant analytic hierarchy process. European Journal of Operational Research, 250: 602614.

ZiraatBankasi. 2013. More Than a Bank for a Hundred and Fifty Years, http://www.ziraat.com.tr/ en/ InvestorRelations/ Documents/ AnnualReports/ AnnualReport2013.pdf, annual report 2013. 